\title{
CD45RO Antibody
}

National Cancer Institute

\section{Source}

National Cancer Institute. CD45RO Antibody. NCI Thesaurus. Code C153104.

Any immunog lobulin that recognizes CD45RO protein. 